\title{
STUDI EKSPERIMENTAL: PERILAKU SIKLIK ANTICOMPRESSION SPLIT-K BRACED STEEL FRAME
}

\author{
Oksa Eberly ${ }^{*}$, Sri Murni Dewi ${ }^{2}$, Wisnumurti ${ }^{2}$ \\ 1Mahasiswa, Program Studi Sarjana, Jurusan Teknik Sipil, Universitas Brawijaya \\ 2Dosen, Jurusan Teknik Sipil, Universitas Brawijaya \\ *Korespondensi: ok.eberly@gmail.com
}

\begin{abstract}
This paper presents an experimental study on the behaviour of a braced steel frame with a proposed system: anticompression brace system (ABS) subjected to cyclic lateral loads. The ABS is proposed to deal with common brace buckling problems. In the study, split-K braced steel frames: with $A B S$ and with ordinary brace system $(O B S)$ were used as speciments. Cyclic loading tests were conducted to evaluate the performance of the proposed system in preventing the brace to buckle and to obtain the behaviour of the frame with ABS compared to the frame with $O B S$ under cyclic quasistatic loading. From the cyclic tests, it was observed that the proposed system worked in preventing the braces to buckle, hence, the aimed state, "buckling prevention" was achieved. The results of the study also show that the frame with ABS had a lower initial stiffness compared to the frame with OBS, nevertheless, after exceeding drift ratio of $0.85 \%$ based on raw data or $0.64 \%$ based on fitted-curves, the frame with $A B S$ exhibited good behaviour through lower degradations in stiffness and cyclic strength relative to the frame with $O B S$ that experienced sudden and greater degradations.
\end{abstract}

Keywords: anticompression brace, buckling failure, cyclic behaviour, cyclic test, tension-only brace.

\section{PENDAHULUAN}

Baja telah menjadi material konstruksi yang banyak digunakan pada era teknik modern, terutama pada seismic area $[1,2]$. Struktur baja selama ini telah dianggap sebagai sebuah solusi yang cocok untuk konstruksi di daerah-daerah dengan aktivitas seismik tinggi dikarenakan sangat baiknya kekuatan dan daktilitas dari struktur baja, serta performa baik yang telah ditunjukan pada banyak gempa bumi ketika prinsip desain seismik masih dikembangkan. Berdasarkan klasifikasi kategori klasik, struktur baja secara umum dibagi menjadi moment resisting frame (MRF), dan braced frame: concentric dan eccentric $[1,3]$.

MRF adalah sistem struktur konvensional, yaitu frame terbuka dengan sambungan balok-kolom yang bersifat dapat menahan momen [3]. Pada daerah rawan gempa, struktur MRF seringkali tidak memiliki kekakuan lateral yang cukup untuk menahan beban gempa, sehingga braced frame umumnya banyak digunakan pada daerah rawan aktivitas seismik [2,4]. Braced frame digunakan untuk mencegah simpangan lateral (drift) yang berlebih dengan menambah kekakuan lateral struktur melalui pemakaian bracing [2,4]. Braced frame dibagi menjadi dua jenis, yaitu concentrically braced frame (CBF), dan eccentrically braced frame (EBF). EBF lebih banyak digunakan pada struktur yang memerlukan opening besar jika dibandingkan dengan CBF. Hal ini dikarenakan konfigurasi perletakan bracing pada EBF yang memiliki segmen "link" atau eksentrisitas dapat memberikan ruang bebas yang lebih luas dibandingkan struktur CBF $[1,3]$.

Meskipun bracing memperkuat struktur dalam arah lateral, tetap saja terdapat kelemahan, yaitu kecenderungan bracing mengalami tekuk (buckling) akibat tekanan dan kelangsingan dari penampang baja [5]. Hal ini menjadi kelemahan utama dari bracing baja pada sistem umumnya; ordinary brace system (OBS), dan akan menjadi masalah serius jika menerima beban siklik [4,5]. Banyak inovasi yang telah dilakukan untuk mengatasi masalah umum pada bracing mengenai tekuk, salah satunya adalah tension-only brace $[2,4,5,6]$. 
Atas dasar inovasi yang telah disebutkan, pada studi ini disusulkan suatu sistem alternatif sederhana untuk dapat mewujudkan kondisi hilangnya mekanisme tekan yang terjadi pada bracing: anticompression brace system (ABS). Diharapkan, ABS dapat bekerja dengan cara memberikan ruang untuk salah satu ujung bracing agar dapat bertranslasi dengan bantuan ball bearing. Displin ilmu rekayasa kegempaan modern cenderung menginginkan tercapainya perilaku siklik yang baik: perilaku histeresis dengan degradasi minimal dan serapan energi maksimal $[4,6]$. Mengingat akan hal tersebut, pada studi ini dilakukan uji pembebanan siklik quasistatic pada salah satu jenis sistem struktur yang banyak digunakan saat ini, EBF, dengan menggunakan ABS dan OBS yang bertujuan untuk mengevaluasi keberhasilan dan mendapatkan gambaran mengenai keunggulan perilaku frame dengan sistem yang diusulkan.

\section{TINJAUAN PUSTAKA}

\subsection{Kekakuan Sistem Struktur}

Kekakuan menggambarkan hubungan antara gaya (aksi) dan perpindahan dari struktur dan/atau komponennya [7,8]. Kekakuan dapat definisikan sebagai kemiringan kurva hubungan aksi gaya-perpindahan dari struktur ataupun komponennya. Kekakuan suatu sistem struktur utamanya dikaitkan dengan fungsi mekanisme tahanan lateralnya [7]. Kekakuan elastik atau awal (initial stiffness) $K_{o}$ struktur sebelum leleh [7,9] dapat ditulis dalam bentuk persamaan (1):

$$
K_{o}=\frac{P_{y}}{\delta_{y}}
$$

dengan $P_{y}$ adalah aksi gaya ketika perpindahan leleh $\delta_{y}$ tercapai. Sedangkan $K_{s}$ merupakan kekakuan sekan (secant stiffness), yaitu kemiringan garis yang berkaitan dengan suatu besar aksi gaya tertentu [7,9]. Kekakuan sekan dapat ditulis sebagai persamaan (2):

$$
K_{s}=\frac{P_{i}}{\delta_{i}}
$$

dengan $P_{i}$ adalah aksi gaya pada level perpindahan $\delta_{i}$. Selain itu, terdapat pula kekakuan tangensial (tangent stiffness) $K_{t}$, yaitu variasi dari nilai kekakuan pada daerah inelastik atau kemiringan pada suatu titik pada kurva respons [7]. Kekakuan tangensial pada suatu titik data eksperimen dapat ditulis sebagai persamaan (3):

$$
K_{t, n}=\frac{P_{n}-P_{n-1}}{\delta_{n}-\delta_{n-1}}
$$

dengan $P_{n}$ merupakan aksi gaya pada step ke- $n$, $P_{n-1}$ adalah aksi gaya pada step ke- $(n-1), \delta_{n}$ adalah perpindahan pada step ke- $n$, dan $\delta_{n-1}$ adalah perpindahan pada step ke-(n - 1). Sedangkan jika garis kurva gaya-perpindahan dinyatakan sebagai fungsi dari perpindahan $\mathrm{f}(\delta)$ $=\mathrm{P}$, maka kekakuan tangensial adalah turunan pertama dari fungsi perpindahan:

$$
K_{t}=f^{\prime}(\delta)=\frac{\partial P}{\partial \delta}
$$

\subsection{Deformasi Lateral Sistem Struktur}

Deformabilitas lateral dari sistem struktur diukur dengan simpangan horizontal (horizontal drift) [7]. Pada gedung, simpangan tingkat (storey drift) $\delta$ adalah perpindahan absolut pada suatu tingkat relatif terhadap dasar. Rasio simpangan pada atap $\delta_{\text {top }}$ terhadap tinggi total struktur $\mathrm{H}$, disebut dengan roof drift ratio DR.

$$
D R=\frac{\delta_{t o p}}{H}
$$

\subsubsection{Definisi Deformasi Leleh}

Beberapa alternatif definisi yang sudah sering digunakan selama ini untuk memperkirakan nilai deformasi leleh adalah sebagaimana yang ditunjukan pada Gambar 1, yaitu (a) perpindahan berdasarkan kelelehan pertama; (b) perpindahan berdasarkan titik leleh dari sebuah sistem elasto-plastic ekivalen dengan kekakuan elastik dan beban ultimate yang sama dengan sistem yang sesungguhnya; (c) Perpindahan berdasarkan titik leleh dari sebuah sistem elasto-plastic ekivalen dengan serapan energi yang sama dengan sistem yang sesungguhnya; (d) Perpindahan berdasarkan titik leleh dari sebuah sistem elasto-plastic ekivalen dengan kekakuan yang tereduksi: sebagai kekakuan sekan pada $75 \%$ dari beban ultimate sistem yang sesungguhnya $[7,10]$.
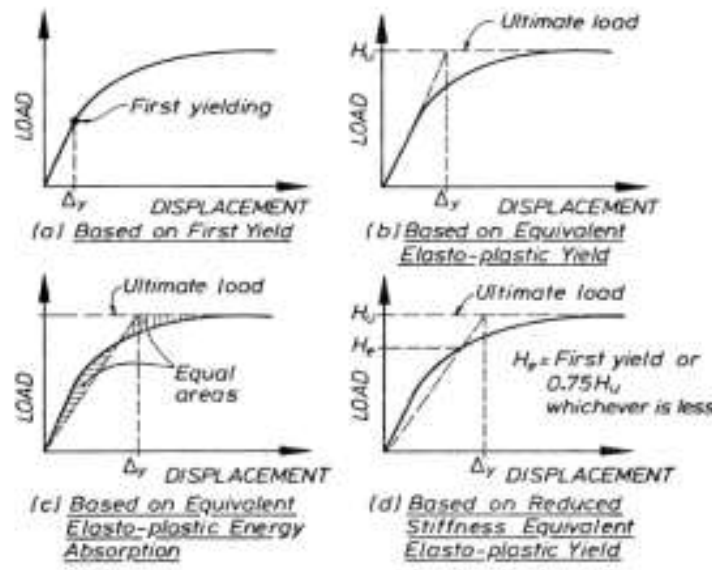

Gambar 1. Definisi Deformasi Leleh [10] 


\subsection{Respons Siklik Struktur}

Respons siklik struktur digambarkan dengan kurva histeresis (hysteresis curve) atau hysteresis loops, yaitu plot aksi gayaperpindahan akibat beban siklik [8]. Berdasarkan responsnya, perilaku siklik sistem struktur dibagi menjadi degradasi kekakuan, degradasi kekuatan, dan pinching [8,11], seperti yang ditunjukan pada Gambar 2.

\subsubsection{Degradasi Kekakuan}

Degradasi kekakuan adalah suatu fenomena tereduksinya kekakuan struktur, baik saat loading ataupun unloading, dan antar siklus ataupun dalam suatu siklus [11]. Banyak komponen dan sistem struktur mengalami degradasi kekakuan pada tingkat tertentu ketika diberikan beban siklik bolak-balik [6,11]. Gambar 2 (a) menunjukkan tiga contoh model degradasi kekakuan.

\subsubsection{Degradasi Kekuatan}

Sistem struktur dapat mengalami pengurangan kekuatan yang disebut degradasi
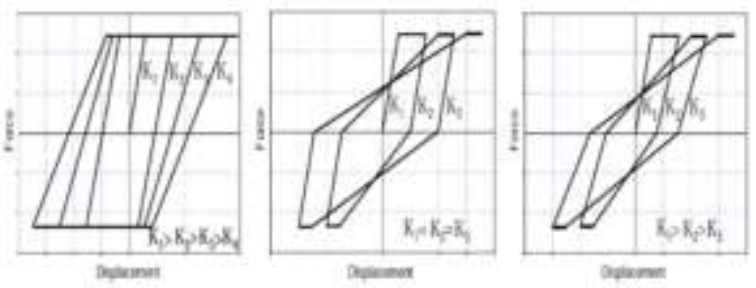

(a)
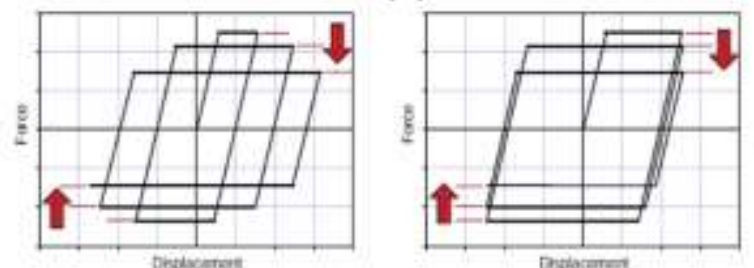

(c) kekuatan (strength degradation) [11]. Gambar 2 (b) menunjukan dua jenis degradasi, yaitu degradasi kekuatan siklik (cyclic strength degradation) dan degradasi kekuatan dalam siklus (in-cycle strength degradation). Pada Gambar 2 (c) ditunjukan contoh degradasi kekuatan siklik (cyclic strength degradation) akibat Pertambahan Perpindahan inelastik dan akibat Perpindahan Siklik Berulang.

\subsubsection{Perilaku Pinching}

Komponen struktur dapat mengalami sebuah fenomena histeretik yang disebut dengan pinching ketika diberikan beban siklik bolakbalik (Gambar 2 (d): sedang dan parah). Perilaku pinching ditandai dengan pengurangan kekakuan yang besar ketika reloading setelah unloading, seiring dengan kembali meningkatnya kekakuan (stiffness recovery) ketika perpindahan terjadi di arah yang berlawanan $[2,8,11]$.
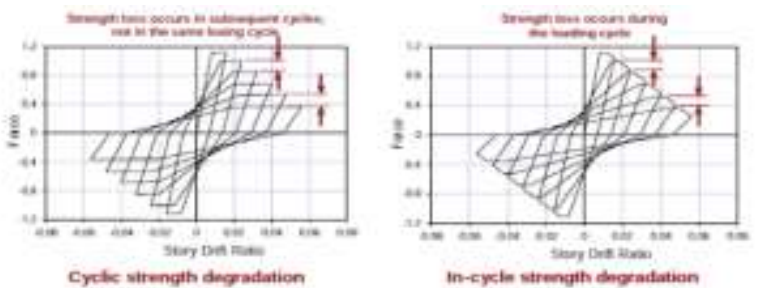

(b)
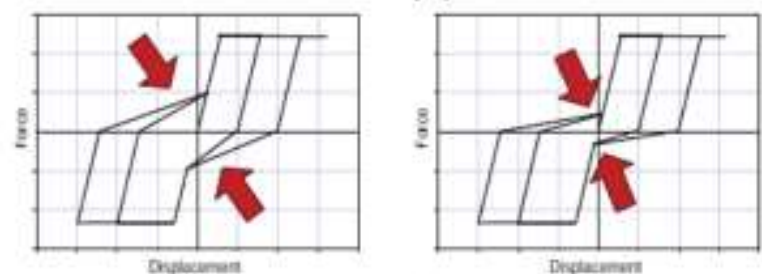

(d)

Gambar 2. Contoh Perilaku Degradasi: (a) Degradasi Kekakuan; (b) Degradasi Kekuatan; (c) Degradasi Kekakuan Siklik; (d) pinching

\subsubsection{Cyclic Envelope}

Cyclic Envelope adalah suatu kurva gayaperpindahan yang membungkus kurva histeresis struktur yang diberikan beban siklik [11], yang dinyatakan dengan cara menghubungkan puncak respons gaya di setiap level perpindahan (step).

\subsection{Tekuk}

Tekuk merupakan sebutan untuk fenomena yang terjadi ketika suatu batang (member) mengalami kegagalan sebelum mencapai kuat nominal dari bahan yang sebenarnya, atau kegagalan akibat instabilitas
[12]. Beberapa faktor yang berperan mempengaruhi terjadinya tekuk antara lain adalah momen inersia penampang, panjang batang, modulus elastisitas atau modulus tangensial, dan faktor panjang efektif yang berkaitan dengan kekangan atau tumpuan. Umumnya tekuk mudah terjadi pada batang langsing yang tertekan $[12,13]$

\subsection{Protokol Uji Siklik Quasi-Statik FEMA 461 \\ Gambar 3 menunjukkan diagram} konseptual deformation-controlled loading history yang direkomendasikan dalam FEMA 461 [14]. Dua siklus untuk setiap amplitudo 
perpindahan, dengan $\Delta_{0}, \Delta_{m}$ berturut-turut adalah level deformasi terkecil (awal) yang ditentukan, dan level deformasi terbesar yang ditargetkan. Nilai amplitudo deformasi suatu step adalah sebesar 1,4 kali dari level deformasi step sebelumnya (bertambah 40\%) [13].

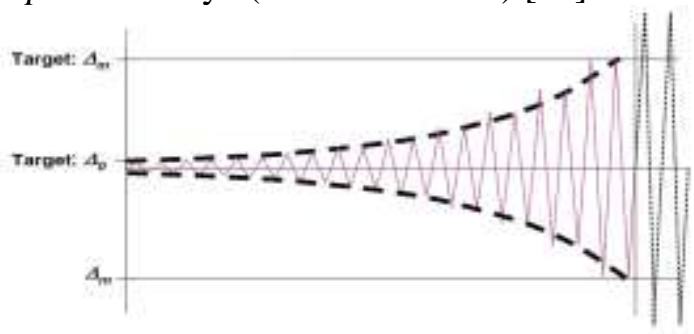

Gambar 3. Sketsa Loading History Kontrol Deformasi [14]

\subsection{Regresi Nonlinier}

Regresi nonlinier adalah teknik untuk mencari hubungan nonlinier antara dua variabel atau lebih, digambarkan melalui kurva pendekatan (fitted-curve) berdasarkan titik-titik dari data yang ada. Keakuratannya diwakilkan dengan koefisien determinasi $\mathrm{R}^{2}$. Sering digunakan regresi dengan transformasi variabel dan regresi polynomial digunakan untuk menyatakan hubungan nonlinier [15].

\section{Metodologi Penelitian}

\subsection{Spesimen Rancangan}

Tabel 1. Variasi Frame Dua Tingkat

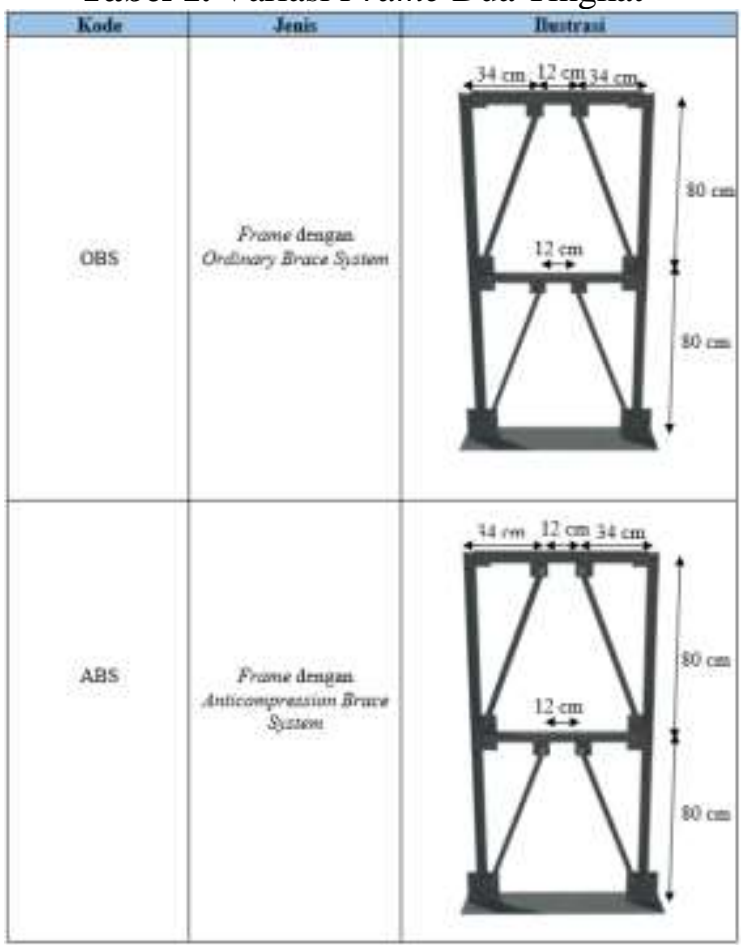

Tabel 2. Penampang Elemen

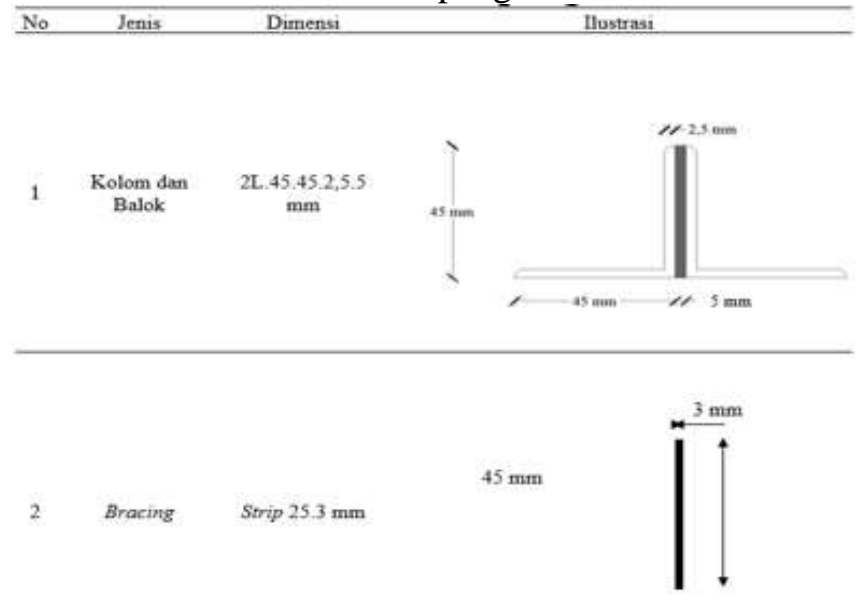

Tabel 3. Detail Joint

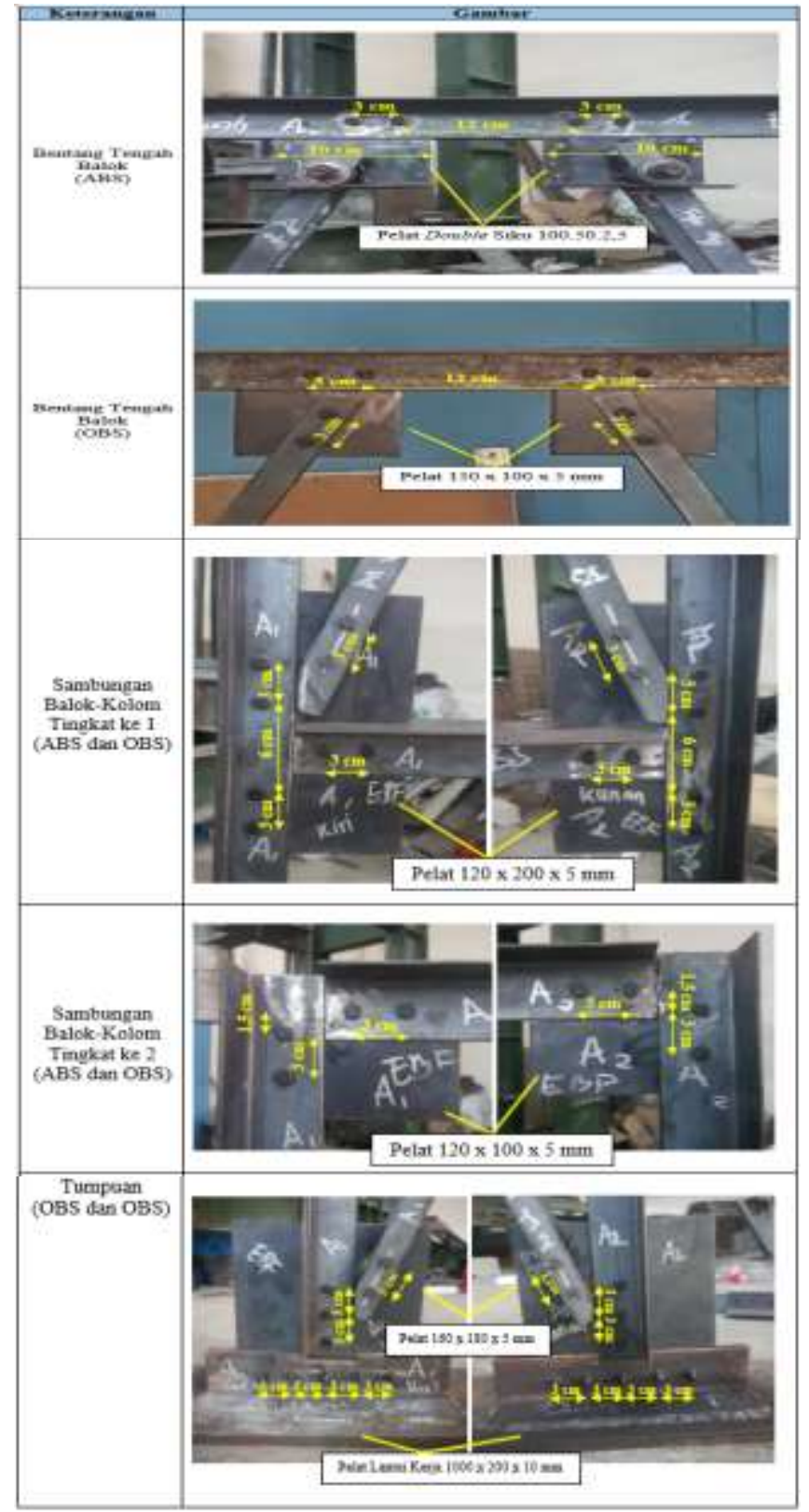

* Jarak baut semua dari pusat ke pusat 
Dalam penelitian ini digunakan dua benda uji frame sebagai spesimen. Tabel 1, Tabel 2, dan Tabel $\mathbf{3}$ berturut-turut menunjukkan ilustrasi variasi spesimen, dan detail joint. Frame disambung ke pelat lantai kerja melalui profil siku 50.50.4 (bolak-balik) yang disambung dengan las keliling. Ball bearing pada ujung bracing diatur sedemikian rupa agar dapat bertranslasi ke arah atas (tegak lurus lintasan pada pelat) dan ke arah dalam struktur (sejajar lintasan pada pelat) dengan memberikan lintasan sepanjang $10 \mathrm{~cm}$ dengan lebar kurang lebih $3 \mathrm{~mm}$ (Gambar 4). Pada bagian ujung lainnya diberikan mur dan ring sebagai pengganjal pada sambungan baut (Gambar 5).

Ball bearing yang digunakan memiliki diameter dalam $12 \mathrm{~mm}$, diameter luar $35 \mathrm{~mm}$, dan tebal $11 \mathrm{~mm}$. Pada sambungan, digunakan baut dengan grade 8.8. Diameter baut yang digunakan adalah $6 \mathrm{~mm}$ untuk sambungan pada pelat buhul dan $12 \mathrm{~mm}$ pada ball bearing. Mur dan ring yang digunakan menyesuaikan dengan ukuran baut.

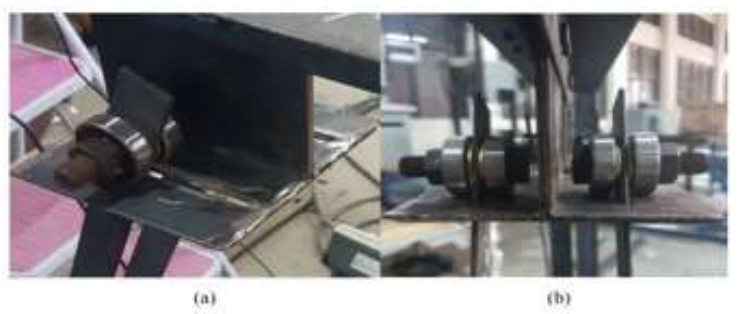

Gambar 4. Perletakan Ball Bearing ABS

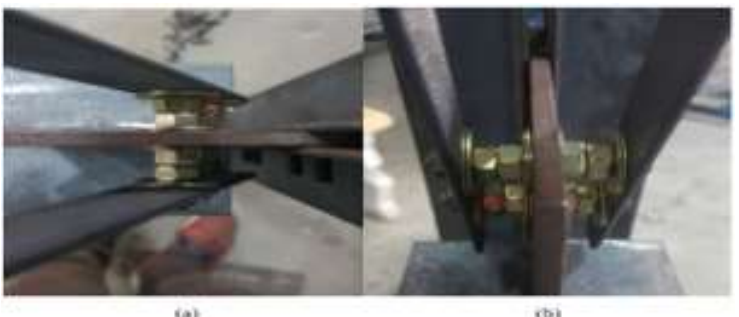

Gambar 5. Sambungan Baut Bracing ABS

\subsection{Loading History}

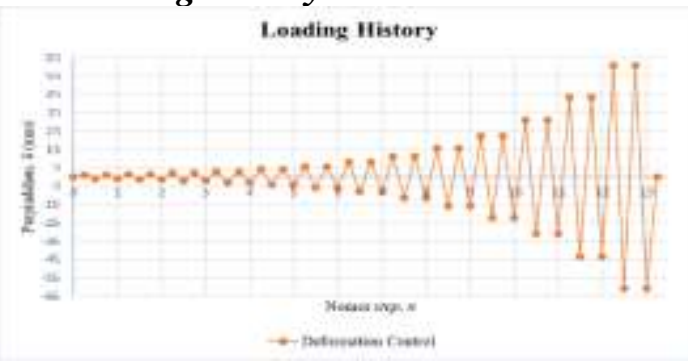

$\begin{array}{clrr}\text { Gambar 6. Sketsa Deformation } & \text { Control } \\ & \text { Loading History } \\ & \text { Digunakan }\end{array}$
Loading history terdiri dari 13 steps: 26 siklus penuh (Gambar 6), dengan deformasi terkecil senilai $1,05 \mathrm{~mm}$ dan deformasi target terbesar senilai $60,77 \mathrm{~mm}$.

\subsection{Tahapan Penelitian}

Secara umum, tahapan kerja pada studi ini diperlihatkan melalui diagram alir pada Gambar 7. Beban siklik yang diberikan pada tahap pengujian adalah loading history pada Gambar 6. Selama uji siklik, dilakukan observasi untuk mengevaluasi performa sistem usulan ABS. Dari uji siklik diambil data perpindahan lateral atau simpangan tingkat benda uji frame yang diberi notasi $\delta$ dan data applied force dari load cell yang disebut sebagai aksi gaya atau beban dan diberi notasi $P$. Datadata tersebut kemudian dikelompokkan berdasarkan masing-masing variasi frame uji, yaitu frame ABS dan frame OBS. Nilai $P$ dan $\delta$ diambil dan dicatat secara langsung saat pengujian. Setelah itu, data diolah untuk mengevaluasi perilaku setiap frame dan menarik kesimpulan.

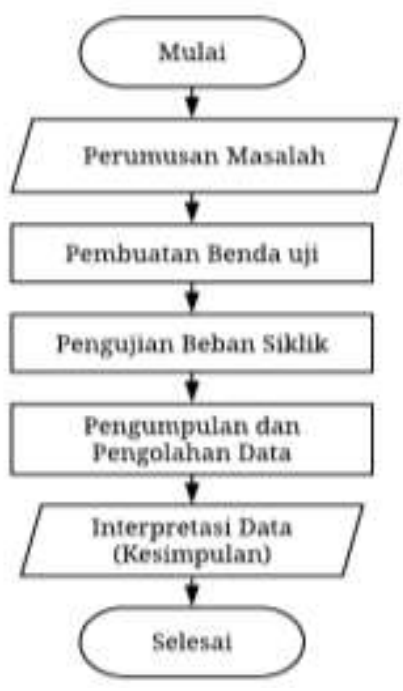

Gambar 7. Diagram Alir Penelitian

\section{HASIL DAN PEMBAHASAN}

\subsection{Pengamatan Visual}

Untuk mengetahui apakah bracing berkerja dalam mencegah tekuk, pengamatan visual dilakukan dengan cara membandingkan kondisi kerusakan bracing pada frame ABS terhadap frame OBS pada saat proses pembebanan berlangsung maupun pada saat setelah proses pembebanan telah selesai. Gambar 8 menunjukkan kondisi bracing pada frame OBS. 
Bracing pada frame OBS terlihat mengalami tekuk (dilingkar merah) yang parah pada saat pembebanan berlangsung (Gambar 8 (a)) maupun pada saat pembebanan berdasarkan loading history telah selesai dilakukan (Gambar 8 (b)).

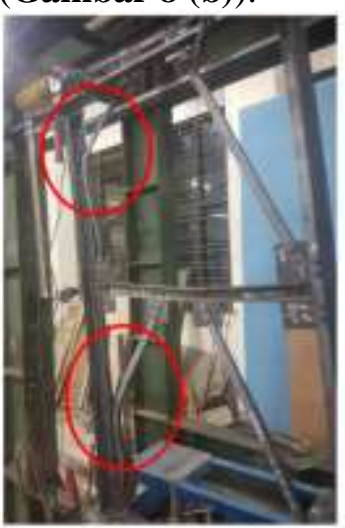

(a)

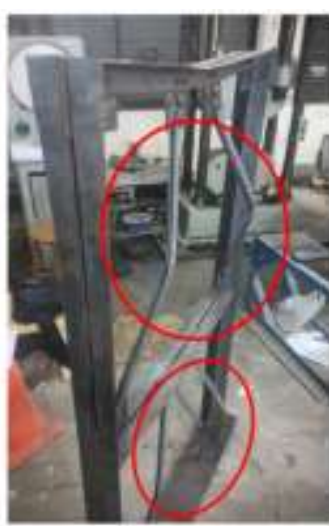

(b)
Gambar 8. Kondisi Bracing Frame OBS

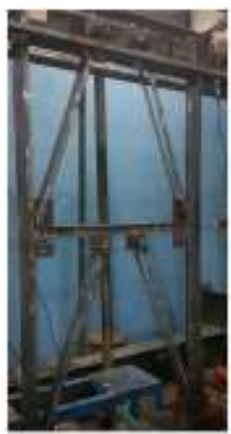

(a)

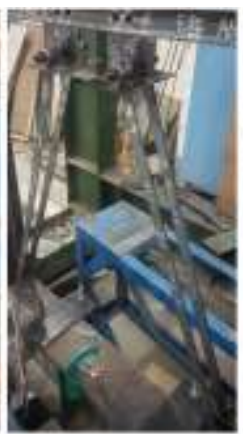

(b)

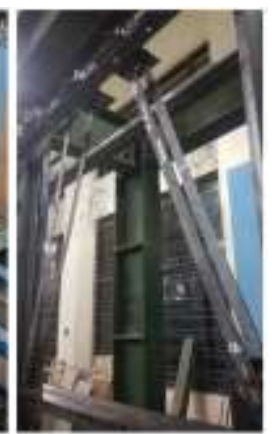

(c)
Gambar 9. Kondisi Bracing Frame ABS

Kondisi bracing pada frame ABS diperlihatkan pada Gambar 9. Baik pada saat pemberian beban (Gambar 9 (a)) maupun pada kondisi akhir saat seluruh pembebanan yang ada pada loading history telah selesai dilakukan (Gambar 9 (b) dan (c)), tidak terlihat adanya tekuk pada seluruh bracing frame ABS. Hal ini mengindikasikan bahwa ABS memang benar berkerja serta berhasil dalam mencegah tekuk yang disebabkan oleh tekanan pada bracing. Adapun peran ball bearing dalam mencegah tekuk ditunjukkan pada Gambar 10. Ball bearing yang ada pada salah satu ujung dari bracing frame ABS mencegah tekanan dengan cara bertranslasi (panah merah), sehingga tekuk tidak terjadi selama masih ada ruang bagi ball bearing untuk dapat bertranslasi. Maka dari itu, frame dengan $\mathrm{ABS}$ memang berkerja dalam mencegah terjadinya tekuk pada bracing.

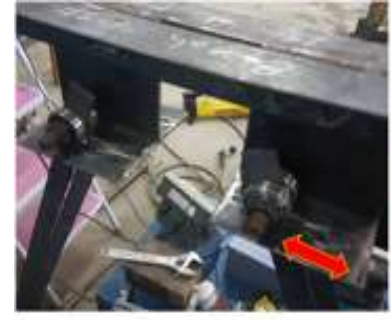

(a)

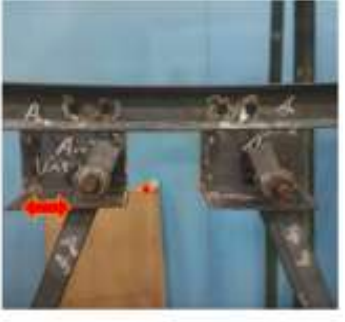

(b)
Gambar 10. Peran Ball Bearing

\subsection{Analisis Perilaku Frame \\ 4.2.1. Cyclic Envelope}

Respons siklik beserta cyclic envelope dari kedua jenis frame ditunjukkan pada Gambar 11. Cyclic envelope untuk selanjutnya akan disebut sebagai envelope curve yang merupakan kurva "bungkus". Untuk mencari keteraturan, dibuat pendekatan persamaan garis envelope curve yang cocok dengan bantuan program Microsoft Excel. Berhubung gaya dan perpindahan terjadi dalam arah yang bolakbalik, pendekatan persamaan kurva akan dibagi menjadi dua arah yaitu arah perpindahan positif yang dinotasikan $\mathrm{E}$ dan arah perpindahan negatif yang dinotasikan W (Gambar 12). Hasilnya, untuk $0<\delta \leq 60,77$, envelope curve didekati dengan fungsi polinomial orde dua untuk frame ABS dan fungsi logaritma untuk frame OBS.

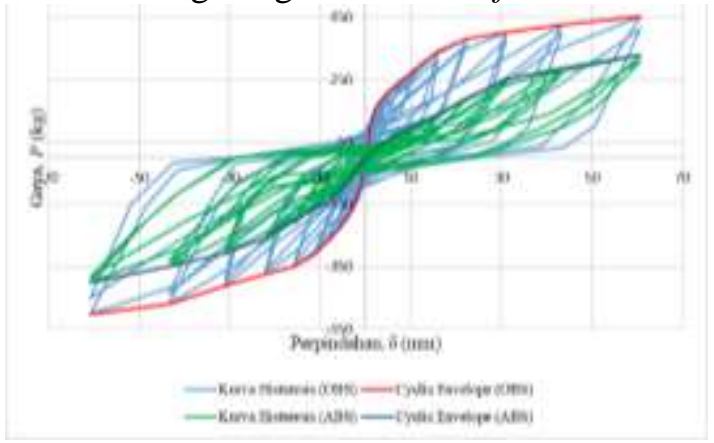

Gambar 11. Respons Siklik Frame

Persamaan envelope curve frame ABS dalam arah $\mathrm{E}$ dan $\mathrm{W}$ berturut-turut adalah sebagai berikut:

$P=-0,0788 \delta^{2}+10,096 \delta+4,6631$

dengan $\mathrm{R}^{2}$ senilai 0,9983 ,

$$
P=-0,1107 \delta^{2}+12,766 \delta+23,874
$$

dengan $\mathrm{R}^{2}$ senilai 0,9918 . Sedangkan persamaan envelope curve frame OBS untuk arah $\mathrm{E}$ dan $\mathrm{W}$ berturut-turut adalah sebagai berikut:

$$
P=90,495 \ln (\delta)+81,14
$$

dengan $\mathrm{R}^{2}$ senilai 0,9882 ,

$$
P=103,66 \ln (\delta)+61,884
$$

dengan $\mathrm{R}^{2}$ senilai 0,9911 . 


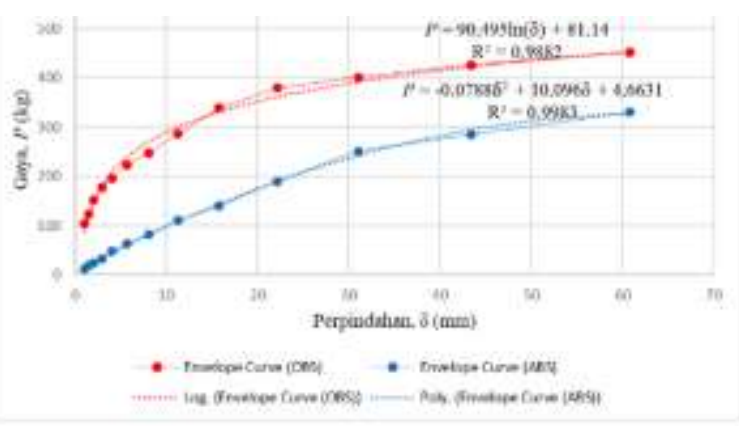

(a)

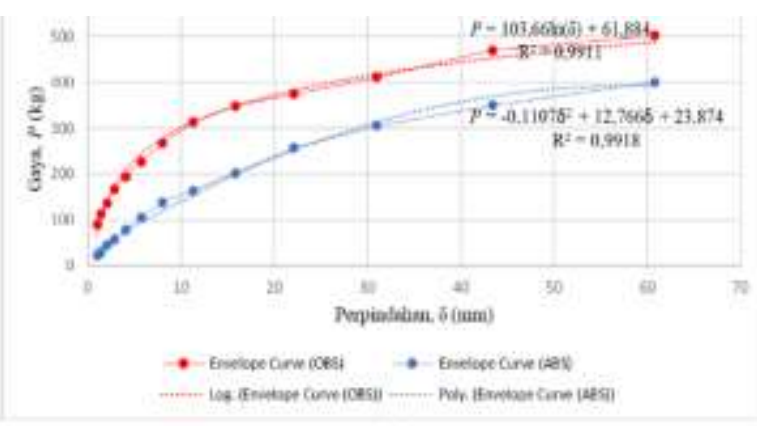

(b)

Gambar 12 (a) Envelope Curve Arah E (b) Envelope Curve Arah W

\subsubsection{Selisih Aksi Gaya Antar Frame}

Selisih aksi gaya $\triangle P$ adalah aksi gaya frame OBS dikurangi aksi gaya frame ABS pada level perpindahan yang sama.

Dapat diamati pada Gambar 13 (a) dan (b) bahwa selisih gaya $P$ antara frame OBS dan frame ABS turun ketika frame telah mencapai nilai perpindahan tertentu pada setiap arah, E dan W, baik menggunakan data mentah eksperimen maupun pendekatan (fitted-curve). Hal tersebut mengindikasikan bahwa terjadi penurunan kekakuan lateral yang lebih besar pada frame OBS setelah mencapai nilai perpindahan tertentu. Berdasarkan hasil data eksperimen, $\Delta P$ menurun setelah melewati perpindahan sebesar 15,82 mm untuk arah $\mathrm{E}$ dan 11,3 mm untuk arah $\mathrm{W}$, yang jika dirata-ratakan didapatkan nilai perpindahan kritis $13,56 \mathrm{~mm}$. Sedangkan untuk data pendekatan hasil

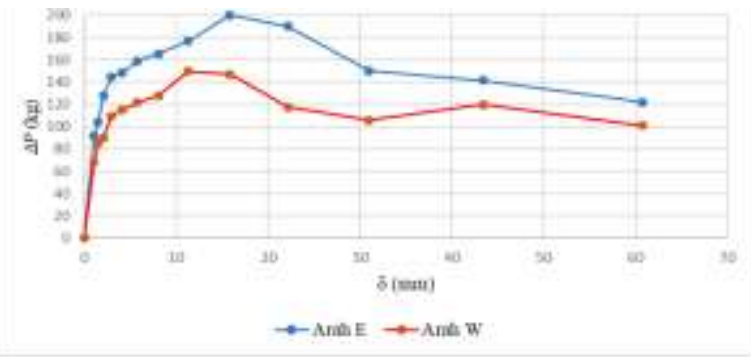

(a) pencocokan kurva, suatu titik perpindahan (kritis) di mana $\Delta P$ akan menurun dapat ditentukan dengan cara menurunkan persamaan (8) dikurangi persamaan (6) dan persamaan (9) dikurangi persamaan (7) lalu disamadengankan nol. Didapatkan nilai perpindahan kritis $\delta$ untuk arah E yaitu $10,78 \mathrm{~mm}$ dan arah $\mathrm{W}$ yaitu 9,78 $\mathrm{mm}$ yang jika dirata-ratakan, didapatkan nilai perpindahan kritis sebesar 10,28 mm. Maka dari itu, berdasarkan hasil analisis menggunakan data mentah dan kurva pendekatan dapat diinterpretasikan setelah melewati level perpindahan (kritis) 13,56 mm (data mentah) atau 10,28 $\mathrm{mm}$ (fitted-curve), yang dapat dinyatakan dalam bentuk drift ratio $D R$ menggunakan persamaan (5) senilai $0,85 \%$ berdasarkan data mentah eksperimen dan $0,64 \%$ berdasarkan persamaan pendekatan (fittedcurve), selisih gaya antara frame $\mathrm{ABS}$ dan frame OBS akan mengecil.

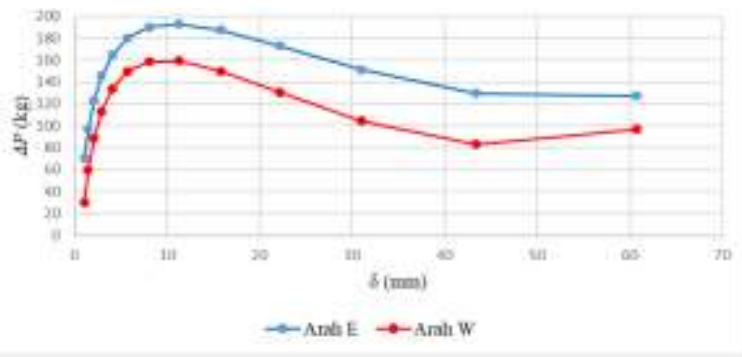

(b)

Gambar 13. Selisih Aksi Gaya pada suatu Level Perpindahan: (a) Data Mentah Eksperimen; (b) Data Pendekatan Hasil Curve Fitting

\subsubsection{Kekakuan Elastik}

Kekakuan elastik atau awal dapat ditentukan dengan terlebih dulu mendefinisikan titik perpindahan leleh $\delta_{y}$ berdasarkan kelelehan pertama (Gambar 14).

Nilai deformasi leleh perkiraan $\delta y$ untuk arah E yaitu 2,1 mm untuk frame OBS dan 11,3 $\mathrm{mm}$ untuk frame ABS. Untuk arah $\mathrm{W}$ didapat nilai deformasi leleh perkiraan $\delta$ y yaitu $2,1 \mathrm{~mm}$ untuk frame OBS dan 8,07 mm untuk frame ABS. Dengan merata-ratakan nilai kekakuan arah $\mathrm{E}$ dan arah $\mathrm{W}$ maka didapat:

$$
\begin{aligned}
K_{0}^{A B S(\text { eksperimen })} & =13,45 \mathrm{~kg} / \mathrm{mm} \\
K_{0}^{A B S(10)}(\text { endekatan }) & =12,22 \mathrm{~kg} / \mathrm{mm}
\end{aligned}
$$


$K_{0}^{O B S(\text { eksperimen })}=68,69 \mathrm{~kg} / \mathrm{mm}$

$K_{0}^{O B S}($ pendekatan $)=68,43 \mathrm{~kg} / \mathrm{mm}$

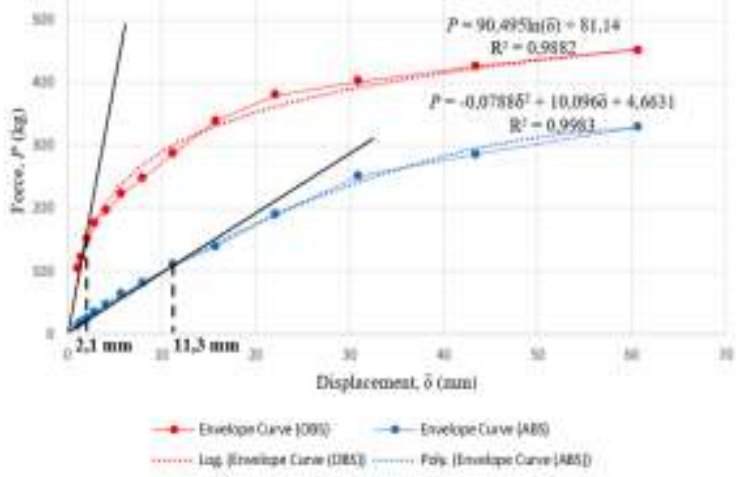

(a)
Dengan demikian, terlihat bahwa kekakuan elastik frame ABS relatif jauh lebih rendah dibandingkan kekakuan elastik frame OBS.

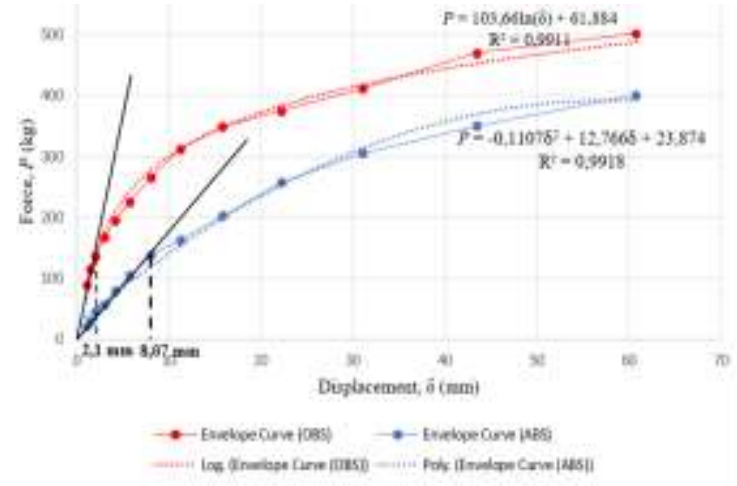

(b)

Gambar 14. Deformasi Leleh: (a) Arah E; (b) Arah W

Nilai deformasi leleh perkiraan $\delta y$ untuk arah E yaitu 2,1 mm untuk frame OBS dan 11,3 $\mathrm{mm}$ untuk frame ABS. Untuk arah $\mathrm{W}$ didapat nilai deformasi leleh perkiraan $\delta$ y yaitu $2,1 \mathrm{~mm}$ untuk frame OBS dan 8,07 mm untuk frame ABS. Dengan merata-ratakan nilai kekakuan arah $\mathrm{E}$ dan arah $\mathrm{W}$ maka didapat:

$K_{0}^{A B S \text { (eksperimen) }}=13,45 \mathrm{~kg} / \mathrm{mm}$

$K_{0}^{A B S \text { (pendekatan) }}=12,22 \mathrm{~kg} / \mathrm{mm}$

$K_{0}^{O B S \text { (eksperimen) }}=68,69 \mathrm{~kg} / \mathrm{mm}$

$K_{0}^{O B S(\text { pendekatan })}=68,43 \mathrm{~kg} / \mathrm{mm}$
Dengan demikian, terlihat bahwa kekakuan elastik frame ABS relatif jauh lebih rendah dibandingkan kekakuan elastik frame OBS.

\subsubsection{Kekakuan Sekan}

Kekakuan sekan $K_{s}$ dihitung dengan persamaan (2). Gambar 15 menunjukkan variasi nilai kekakuan sekan $K_{s}$ relatif terhadap kekakuan awalnya $K_{0}$. kekakuan elastik frame OBS. Dapat dilihat nilai $K_{s} / K_{0}$ pada frame ABS (garis biru) berkurang secara lebih perlahan jika dibandingkan dengan nilai $K_{s} / K_{0}$ pada frame OBS (garis merah) yang cenderung berkurang secara tiba-tiba atau drastis.

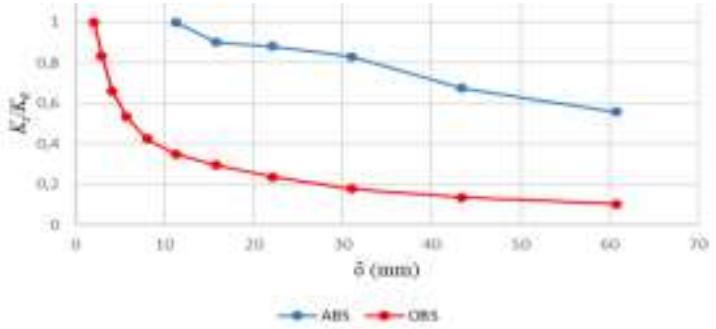

(a)

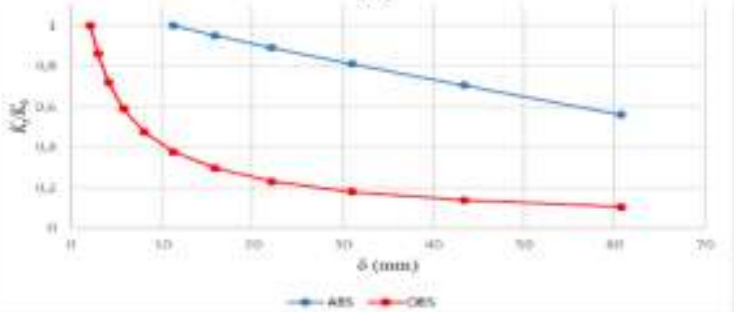

(c)

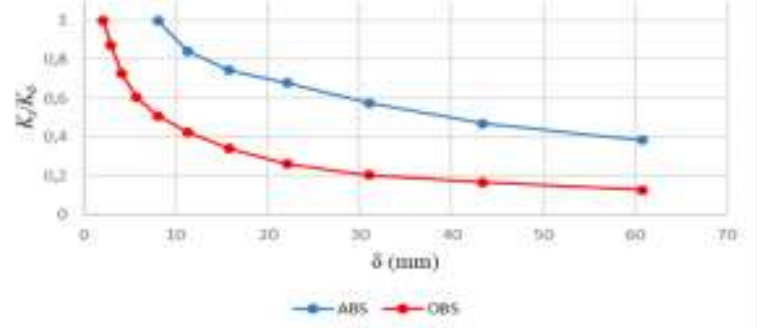

(b)

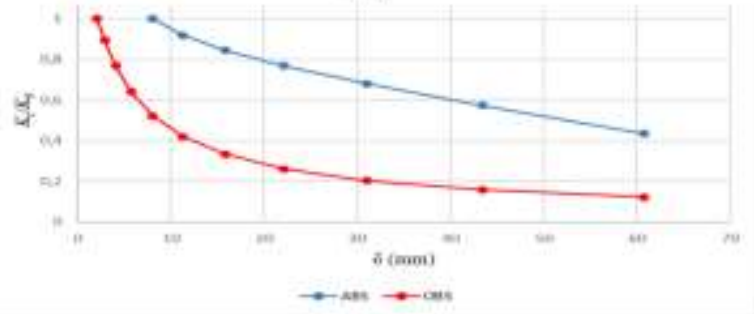

(d)

Gambar 15. Rasio Kekakuan Sekan Relatif Terhadap Kekakuan Elastik: (a) Data Mentah Eksperimen Arah E; (b) Data Mentah Eksperimen Arah W; (c) Data Pendekatan Arah E; (d) Data Pendekatan Arah W 
Level perpindahan kritis: drift ratio $0,85 \%$ (data mentah) atau $0,64 \%$ (fitted-curve) merupakan titik dimana selisih $K_{\mathrm{s}}$ antara frame ABS dan frame OBS berbalik dari yang semula semakin besar, menjadi semakin kecil.

\subsubsection{Kekakuan Tangensial}

Kekakuan tangensial berdasarkan data mentah eksperimen dihitung dengan menggunakan persamaan (3) (Gambar 16(a)), sedangkan berdasarkan persamaan pendekatan (fitted-curve) dihitung dengan menggunakan persamaan (4) (Gambar 16(b)). Dapat diamati bahwa nilai kekakuan tangensial frame $\mathrm{ABS}$ pada arah $\mathrm{E}$ (perpindahan positif) dan arah $\mathrm{W}$

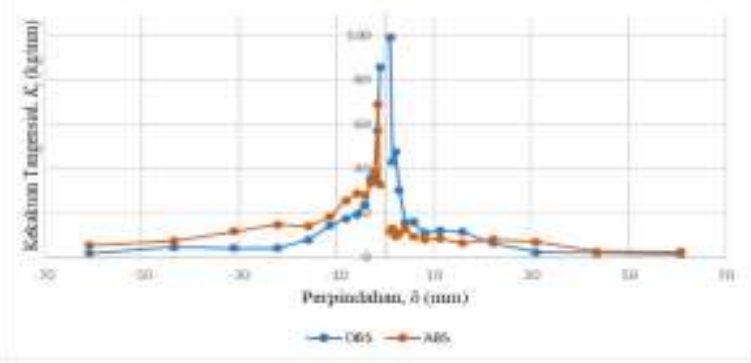

(a) (perpindahan negatif) cenderung akan melewati kekakuan tangensial frame OBS ketika telah melewati titik perpindahan tertentu. Hal ini menunjukkan perilaku yang serupa dengan kekakuan sekan, dimana nilai kekakuan tangensial akan turun secara lebih perlahan seiring membesarnya perpindahan untuk frame ABS. Perpindahan kritis yang telah dibahas sebelumnya adalah titik dimana jika besarnya perpindahan telah melewati nilai tersebut, maka kekakuan tangensial frame ABS berbalik menjadi lebih besar daripada yang dimiliki frame OBS.

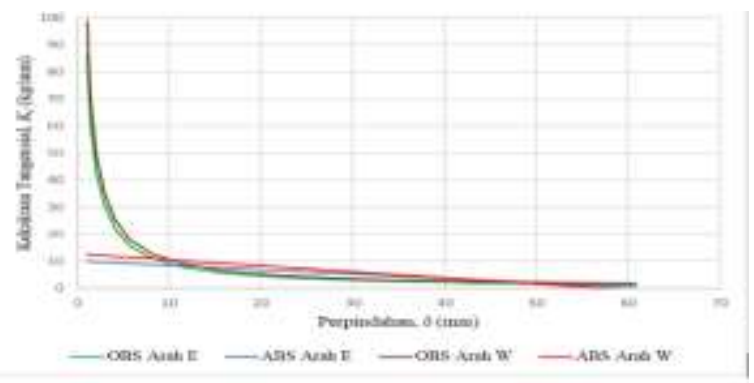

(b)

Gambar 16. Plot Kekakuan Tangensial vs Perpindahan: (a) Data Mentah; (b) Data Pendekatan

\subsubsection{Perilaku Histeresis}

Perilaku degradasi kekuatan siklik (cyclic strength degradation) terjadi pada kedua frame (Gambar 17(a)), sedangkan untuk perilaku degradasi kekuatan dalam siklus (in-cycle strength degradation) tidak dapat ditemukan sepanjang jangkauan perpindahan pengamatan $(60,77 \mathrm{~mm})$. Nilai degradasi kekuatan siklik ditunjukkan pada Gambar 18. Terlihat pada level perpindahan besar (di atas perpindahan kritis), degradasi kekuatan yang dialami frame ABS lebih rendah dibandingkan frame OBS.

Gambar 17(b) dapat dilihat bahwa kedua frame uji (ABS maupun OBS) menunjukkan perilaku pinching: terjadi reduksi kekakuan ketika melakukan reloading setelah unloading, lalu terjadi stiffness recovery pada arah yang berlawanan.

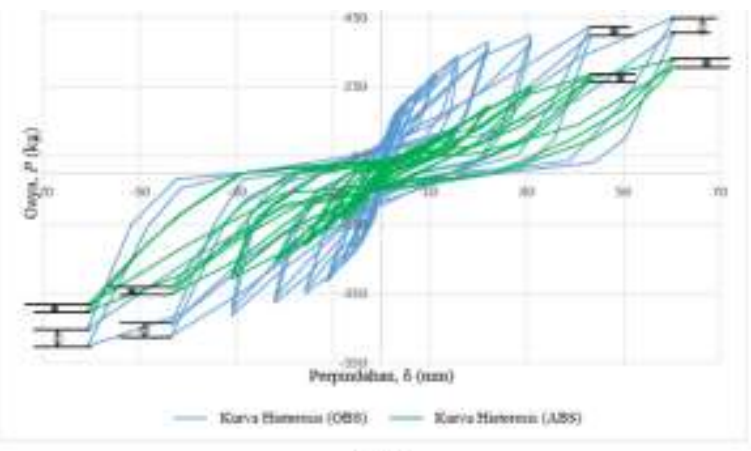

(a)

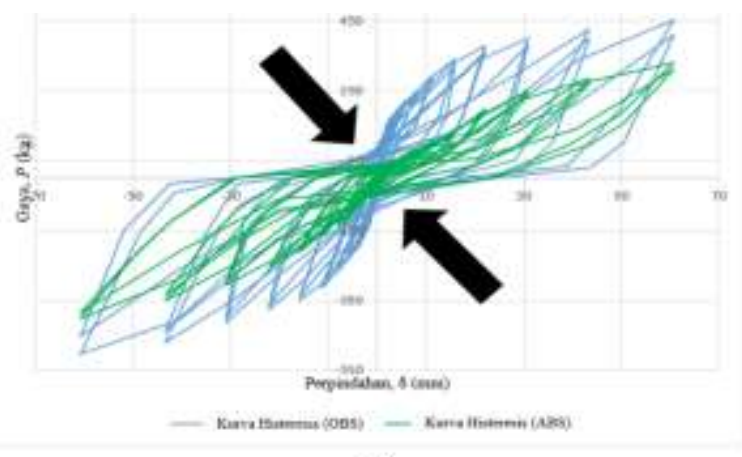

(b)

Gambar 17. Perilaku Histeresis: (a) Degradasi Kekakuan; (b) Pinching 


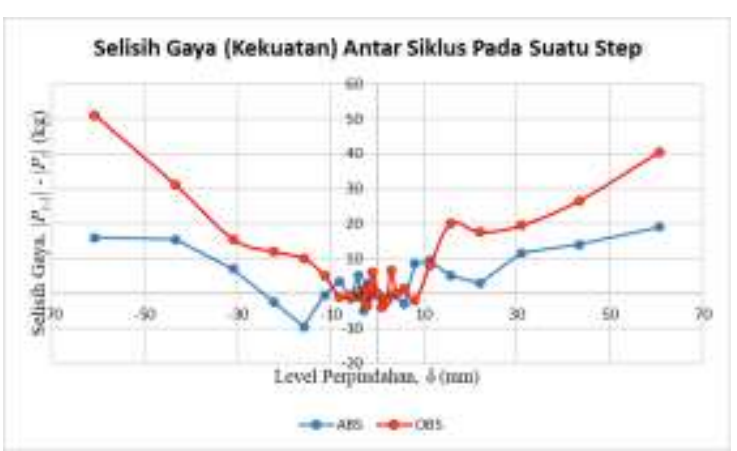

Gambar 18. Nilai Degradasi Kekakuan Siklik dalam suatu Step

Dengan adanya degradasi kekuatan siklik, serta telah dibahas tentang berkurangnya kekakuan frame sebelumnya, maka jelaslah bahwa terdapat degradasi kekakuan siklik maupun degradasi kekakuan in-cycle sebagai fungsi dari perpindahan puncak pada kedua frame uji (kekakuan loading).

\section{PENUTUP}

\subsection{Kesimpulan}

Berdasarkan hasil dan pembahasan, dapat dibuat kesimpulan sebagai berikut:

1. Split-K Braced Steel Frame dengan ABS memiliki kekakuan elastik yang lebih rendah dibandingkan dengan OBS, namun setelah melewati drift ratio kritis senilai $0,85 \%$ berdasarkan data mentah eksperimen dan $0,64 \%$ berdasarkan hasil pendekatan pencocokan kurva, frame dengan ABS menunjukkan perilaku yang baik melalui rendahnya degradasi kekakuan dan kekuatan siklik dibandingkan frame dengan OBS yang mengalami degradasi kekakuan dan kekuatan secara relatif drastis. Dimulai dari drift ratio kritis hingga perpindahan puncak pengamatan sebesar $60,77 \mathrm{~mm}$, kurva gayaperpindahan frame dengan ABS bergerak semakin mendekati kurva gaya-perpindahan frame dengan OBS. Dalam desain seismik dengan design point yang melebihi nilai drift ratio kritis, penggunaan ABS dapat dipertimbangkan sebagai alternatif yang baik untuk sistem struktur dalam hal meminimalisir reduksi kekuatan dan kekakuan yang mendadak.

2. Split-K braced steel frame dengan ABS yang diusulkan terlihat berkerja dalam mencegah terjadinya tekuk pada bracing yang ditandai dengan bertranslasinya ball bearing dan tidak adanya tekukan pada seluruh bracing pada frame dengan ABS, hal sebaliknya terjadi pada frame dengan OBS.

\subsection{Saran}

Saran yang dapat diberikan untuk penelitian selanjutnya adalah sebagai berikut:

1. Menambahkan mekanisme self-centering pada frame.

2. Mempertimbangkan efek tumbuk yang terjadi akibat tumbukan ball bearing pada struktur jika dikenakan beban dinamik.

3. Memilih penampang yang pusat beratnya berhimpit dengan pusat geser (kekakuan torsi tinggi) untuk menghindari terjadinya torsi yang parah saat pembebanan siklik.

\section{DAFTAR PUSTAKA}

[1] Gioncu, V., \& Mazzolani, F. M. (2014). Seismic Design of Steel Structures. Boca Raton: CRC Press.

[2] Wang, W., Zhou, Q., Chen, Y., Tong, L., \& Chan, T.-M. (2013). Experimental and Numerical Investigation on Full-Scale Tension-Only Concentrically Braced Steel Beam-Through Frames. Journal of Constructional Steel Research, 80, 369-385.

[3] Bruneau, M., Uang, C.-M., \& Sabelli, R. (2011). Ductile Design of Steel Structures. New York: McGraw Hill.

[4] Chi, P., Tian, W., Guo, T., Cao, D., \& Dong, J. (2019). Parametric Study on the Seismic Response of Steel-Framed Buildings with Self-Centering Tension-Only Braces. Advances in Civil Engineering, 2019, 9204362.

[5] Papagiannopoulos, G. A. (2018). On the Seismic Behaviour of Tension-Only Concentrically Braced Steel Structures. Soil Dynamics and Earthquake Engineering, 115, 27-35.

[6] Zahrai, S. M., Mousavi, S. A., \& Saatcioglu, M. (2017). Analytical Study on Seismic Behavior of Proposed Hybrid Tension-Only Braced Frames. Struct. Design Tall Spec. Build, doi: 10.1002/tal.1310.

[7] Elnashai, A. S., \& Sarno, L. D. (2015). Fundamentals of Earthquake Engineering: From Source to Fragility. West Sussex: John Wiley \& Sons.

[8] Pawirodikromo, W. (2017). Analisis Dinamik Struktur. Yogyakarta: Pustaka Pelajar.

[9] Sullivan, T. J., Calvi, G. M., \& Priestley, M. N. (2004). Initial Stiffness Versus Secant Stiffness in Displacement Based Design. 
13th World Conference on Earthquake Engineering. Vancouver

[10]Park, R. (1989). Evaluation of Ductility of Structures and Structural Assemblages from Laboratory Testing. Bulletin of the New Zealand National Society for Earthquake Engineering, 22(3), 155-166.

[11] Federal Emergency Management Agency. (2009). FEMA P440A: Effect of Strength and Stiffness Degradation on Seismic Response. Washington D.C.: Federal Emergency Management Agency.

[12] Segui, W. T. (2013). Steel Design. Stamford: Cengage Learning.
[13]Dewi, S. M., \& Dobana, K. (2007). Stabilitas Bangunan Baja. Malang: Bargie Media.

[14]Federal Emergency Management Agency. (2007). FEMA 461: Interim Testing Protocols for Determining the Seismic Performance Characteristics of Structural and Nonstructural Components. Washington D.C: Federal Emergency Management Agency.

[15] Devore, J. L. (2012). Probability and Statistics for Engineering and Sciences. Boston: Cengage/Cole, Cengage Learning. 